Film Serials and the American Cinema, 1910-1940 



\title{
Film Serials and the American Cinema, 1910-1940
}

Operational Detection

\author{
Ilka Brasch
}


Cover illustration: Pearl White shooting scenes for The Perils of Pauline in Fort Lee, 1914. Photo Courtesy of the Fort Lee Film Commission of Fort Lee, NJ USA.

Cover design: Kok Korpershoek, Amsterdam

Lay-out: Crius Group, Hulshout

Amsterdam University Press English-language titles are distributed in the US and Canada by the University of Chicago Press.

$\begin{array}{ll}\text { ISBN } & 97894629865^{2} 7 \\ \text { e-ISBN } & 9789048537808 \\ \text { DOI } & 10.5117 / 97894629865^{27} \\ \text { NUR } & 670\end{array}$

(C) I. Brasch / Amsterdam University Press B.V., Amsterdam 2018

All rights reserved. Without limiting the rights under copyright reserved above, no part of this book may be reproduced, stored in or introduced into a retrieval system, or transmitted, in any form or by any means (electronic, mechanical, photocopying, recording or otherwise) without the written permission of both the copyright owner and the author of the book.

Every effort has been made to obtain permission to use all copyrighted illustrations reproduced in this book. Nonetheless, whosoever believes to have rights to this material is advised to contact the publisher. 